\title{
Engineering Geobacillus thermodenitrificans to introduce cellulolytic activity; expression of native and heterologous cellulase genes
}

Martinus J. A. Daas ${ }^{1}$, Bart Nijsse², Antonius H. P. van de Weijer', Bart W. A. J. Groenendaal ${ }^{1}$, Fons Janssen ${ }^{1}$, John van der Oost ${ }^{1}$ and Richard van Kranenburg ${ }^{1,3^{*}}$ (D)

\begin{abstract}
Background: Consolidated bioprocessing (CBP) is a cost-effective approach for the conversion of lignocellulosic biomass to biofuels and biochemicals. The enzymatic conversion of cellulose to glucose requires the synergistic action of three types of enzymes: exoglucanases, endoglucanases and $\beta$-glucosidases. The thermophilic, hemicellulolytic Geobacillus thermodenitrificans T12 was shown to harbor desired features for CBP, although it lacks the desired endo and exoglucanases required for the conversion of cellulose. Here, we report the expression of both endoglucanase and exoglucanase encoding genes by G. thermodenitrificans T12, in an initial attempt to express cellulolytic enzymes that complement the enzymatic machinery of this strain.
\end{abstract}

Results: A metagenome screen was performed on $73 \mathrm{G}$. thermodenitrificans strains using HMM profiles of all known CAZy families that contain endo and/or exoglucanases. Two putative endoglucanases, GE39 and GE40, belonging to glucoside hydrolase family 5 (GH5) were isolated and expressed in both E. coli and G. thermodenitrificans T12. Structure modeling of GE39 revealed a folding similar to a GH5 exo-1,3- $\beta$-glucanase from $S$. cerevisiae. However, we determined GE39 to be a $\beta$-xylosidase having pronounced activity towards $p$-nitrophenyl- $\beta$-D-xylopyranoside. Structure modelling of GE40 revealed its protein architecture to be similar to a GH5 endoglucanase from $B$. halodurans, and its endoglucanase activity was confirmed by enzymatic activity against 2-hydroxyethylcellulose, carboxymethylcellulose and barley $\beta$-glucan. Additionally, we introduced expression constructs into T12 containing Geobacillus sp. 70PC53 endoglucanase gene celA and both endoglucanase genes (M1 and M2) from Geobacillus sp. WSUCF1. Finally, we introduced expression constructs into T12 containing the $C$. thermocellum exoglucanases celK and cels genes and the endoglucanase celC gene.

Conclusions: We identified a novel G. thermodenitrificans $\beta$-xylosidase (GE39) and a novel endoglucanase (GE40) using a metagenome screen based on multiple HMM profiles. We successfully expressed both genes in E. coli and functionally expressed the GE40 endoglucanase in G. thermodenitrificans T12. Additionally, the heterologous production of active CelK, a C. thermocellum derived exoglucanase, and CelA, a Geobacillus derived endoglucanase, was demonstrated with strain T12. The native hemicellulolytic activity and the heterologous cellulolytic activity described in this research provide a good basis for the further development of G. thermodenitrificans T12 as a host for consolidated bioprocessing.

Keywords: Geobacillus, Metagenome, $\beta$-Xylosidase, Cellulase, CBP

\footnotetext{
* Correspondence: richard.vankranenburg@wur.nl

${ }^{1}$ Laboratory of Microbiology, Wageningen University, Stippeneng 4, 6708,

WE, Wageningen, The Netherlands

${ }^{3}$ Corbion, Arkelsedijk 46, 4206, AC, Gorinchem, The Netherlands

Full list of author information is available at the end of the article
}

(c) The Author(s). 2018 Open Access This article is distributed under the terms of the Creative Commons Attribution 4.0 International License (http://creativecommons.org/licenses/by/4.0/), which permits unrestricted use, distribution, and reproduction in any medium, provided you give appropriate credit to the original author(s) and the source, provide a link to the Creative Commons license, and indicate if changes were made. The Creative Commons Public Domain Dedication waiver (http://creativecommons.org/publicdomain/zero/1.0/) applies to the data made available in this article, unless otherwise stated. 


\section{Background}

Lignocellulosic biomass is considered a potential alternative to fossil resources as substrate for biofuels and biochemicals. Although lignocellulosic biomass itself is cheap, saccharification of this substrate is costly due to the variety and amounts of enzymes needed for its conversion. In order to reduce costs of this conversion, Lynd et al. [1] proposed consolidated bioprocessing (CBP) as the most promising solution. CBP requires an organism capable of saccharolytic enzyme production and fermentation of the released sugars. Even if CBP could not be completely achieved, improving hemicellulolytic and cellulolytic activity will be economically attractive.

Clostridium thermocellum is considered an excellent candidate for CBP due to the production of a variety of cellulosic enzymes and its thermophilic nature [2]. The use of a thermophile offers several advantages like reduced contamination risk, reduced substrate viscosity and reduced energy demand for cooling [3]. The downside of $C$. thermocellum is that it is not able to ferment C5 sugars released from the lignocellulosic substrate and thus requires extensive engineering of metabolic pathways or the use of co-culturing with pentose utilizing microbes [4-6].

Alternatively, a candidate CBP organism can be derived from the genus Geobacillus. Species from this genus are thermophilic, facultative anaerobes that are able to degrade and metabolize hemicellulose [7-9]. For example, Geobacillus thermodenitrificans strain T12 has an extensive hemicellulose utilization locus that also includes the capacity to degrade pectin [10]. Unlike $C$. thermocellum, most Geobacillus strains are not able to efficiently degrade cellulose, even when isolated from microcrystalline cellulose or composted plant biomass $[11,12]$. In the majority of isolates $\beta$-glucosidases are present, but endo and exoglucanases are missing. Several isolates with endoglucanase activity have been reported, however, the endoglucanase CelA from Geobacillus sp. 70PC53 is to date the only characterized true cellulolytic enzyme native to Geobacillus spp. [11, 13]. In a recent study on the isolation of Geobacillus strains we showed that several strains of $G$. thermodenitrificans were able to grow on carboxymethyl cellulose, and for some of these strains clear degradation of cellulose was demonstrated by using the Congo red assay [12]. Taken together, these findings demonstrate that genes encoding cellulolytic enzymes are present across the genus Geobacillus, although so far only endoglucanases have been found.

An approach to overcome the hurdle of cellulose conversion is to engineer the required cellulose encoding genes into a suitable host of the genus Geobacillus [14]. The expression of a heterologous endoglucanase
(WP_010885255.1) from Pyrococcus horikoshii in G. kaustophilus HTA26 enabled this mutant strain to degrade carboxymethylcellulose and filter paper [15]. However, for complete hydrolysis of cellulose both endo and exoglucanases are required and the HTA426 strain lacks genes required for hemicellulose conversion, making it less suited for CBP [16].

Heterologous production of $C$. thermocellum cellulases has been demonstrated in Bacillus subtillis [17]. Here, the production of CelK (reducing end exoglucanase; GH 9) and CelS (non-reducing end exoglucanase; GH48) was demonstrated by the clearing zones of mutant colonies on CMC plates. Both exoglucanases described are also highly expressed in $C$. thermocellum when grown on cellulosic and lignocellulosic substrates and are therefore expected to be of great importance for the cellulolytic activity of C. thermocellum [18-20].

In this study, we screened the metagenome of 73 Geobacillus thermodenitrificans isolates for novel endo and exoglucanases. Subsequently, three Geobacillus derived endoglucanases were expressed in E. coli and G. thermodenitrificans T12. To complement the cellulolytic activity of strain T12 we also introduced an endoglucanase (celC) and two exoglucanases (celK and celS) from $C$. thermocellum.

This is the first study on the expression of a full set of cellulolytic enzymes in Geobacillus and thereby provides new insights in the applicability of members of this genus as potential hosts for consolidated bioprocessing.

\section{Methods}

\section{Media, strains, primers and constructs}

Cellulolytic Thermophile Vitamin Medium (CTVM; based on [7, 21-23]) contained per liter: $8.37 \mathrm{~g}$ MOPS; 1 g NH 4 Cl; 3 g NaCl; 1.50 g Na$_{2} \mathrm{SO}_{4} ; 0.08$ g NaHCO ; $1 \mathrm{~g} \mathrm{KCl} ; 1.8 \mathrm{~g} \mathrm{MgCl}_{2} \times 6 \mathrm{H}_{2} \mathrm{O} ; 0.30 \mathrm{~g} \mathrm{CaCl}_{2} \times 2 \mathrm{H}_{2} \mathrm{O} . \mathrm{pH}$ was set to 6.6 at room temperature and the medium was autoclaved for $20 \mathrm{~min}$ at $121{ }^{\circ} \mathrm{C}$, after which $1 \mathrm{~mL}$ $\mathrm{K}_{2} \mathrm{HPO}_{4}(250 \mathrm{~g} / \mathrm{L} ; \mathrm{pH}$ 6.6), $10 \mathrm{~mL}$ filter sterile $100 \times$ metal mix and $1 \mathrm{~mL}$ filter sterile $1000 \times$ vitamin solution were added. $100 \times$ metal mix contained per liter: $1.60 \mathrm{~g}$ $\mathrm{MnCl}_{2} \times 6 \mathrm{H}_{2} \mathrm{O} ; 0.1$ g $\mathrm{ZnSO}_{4} ; 0.2$ g $\mathrm{H}_{3} \mathrm{BO}_{3} ; 0.01 \mathrm{~g}$ $\mathrm{CuSO}_{4} \times 5 \mathrm{H}_{2} \mathrm{O} ; 0.01 \mathrm{~g} \mathrm{Na}_{2} \mathrm{MoO}_{4} \times 2 \mathrm{H}_{2} 0 ; 0.1 \mathrm{~g} \mathrm{CoCl}_{2} \times$ $6 \mathrm{H}_{2} \mathrm{O} ; 0.7 \mathrm{~g} \mathrm{FeSO}_{4} \times 7 \mathrm{H}_{2} \mathrm{O} ; 5 \mathrm{~g} \mathrm{CaCl}_{2} \times 2 \mathrm{H}_{2} \mathrm{O} ; 20 \mathrm{~g}$ $\mathrm{MgCl}_{2} \times 6 \mathrm{H}_{2} \mathrm{O}$. $1000 \times$ vitamin mix contained per liter: $0.1 \mathrm{~g}$ thiamine; $0.1 \mathrm{~g}$ riboflavin; $0.5 \mathrm{~g}$ nicotinic acid; $0.1 \mathrm{~g}$ pantothenic acid; $0.5 \mathrm{~g}$ pyridoxamine, $\mathrm{HCl} ; 0.5 \mathrm{~g}$ pyridoxal, $\mathrm{HCl}$; 0.1 g D-biotin; $0.1 \mathrm{~g}$ folic acid; $0.1 \mathrm{~g} p$-aminobenzoic acid; $0.1 \mathrm{~g}$ cobalamin.

LB2 contained per liter: $10 \mathrm{~g}$ tryptone (Oxoid), $5 \mathrm{~g}$ yeast extract (Roth), $10 \mathrm{~g}$ sodium chloride and salts mix consisting of $1 \mathrm{~g} \mathrm{NH}{ }_{4} \mathrm{Cl} ; 3 \mathrm{~g} \mathrm{NaCl} ; 1.50 \mathrm{~g} \mathrm{Na}_{2} \mathrm{SO}_{4}$; $0.08 \mathrm{~g} \mathrm{NaHCO} ; 1 \mathrm{~g} \mathrm{KCl} ; 1.8 \mathrm{~g} \mathrm{MgCl}_{2} \times 6 \mathrm{H}_{2} \mathrm{O} ; 0.30 \mathrm{~g}$ $\mathrm{CaCl}_{2} \times 2 \mathrm{H}_{2} \mathrm{O}$. pH was set to 6.6 at room temperature 
and the medium was autoclaved for $20 \mathrm{~min}$ at $121{ }^{\circ} \mathrm{C}$, after which $10 \mathrm{~mL} \mathrm{~K} \mathrm{HPO}_{4}(250 \mathrm{~g} / \mathrm{L})$ was added.

Minimal Media (MM) contained per liter: $0.52 \mathrm{~g}$ $\mathrm{K}_{2} \mathrm{HPO}_{4} ; 0.23 \mathrm{~g} \mathrm{KH}_{2} \mathrm{PO}_{4} ; 0.5 \mathrm{~g} \mathrm{NH}_{4} \mathrm{NO}_{3}$ (MMy) or $0.3 \mathrm{~g}$ $\mathrm{NH}_{4} \mathrm{Cl}(\mathrm{MMy}+)$. After autoclaving, $1 \mathrm{~mL}$ of the following 1,000× concentrated sterile stocks were added: Nitrilotriacetic acid $(200 \mathrm{~g} / \mathrm{L}) ; \mathrm{MgSO}_{4} \times 7 \mathrm{H}_{2} \mathrm{O}(145.44 \mathrm{~g} / \mathrm{L})$; $\mathrm{CaCl}_{2} \times 2 \mathrm{H}_{2} \mathrm{O}(133.78 \mathrm{~g} / \mathrm{L}) ; \mathrm{FeSO}_{4} \times 7 \mathrm{H}_{2} \mathrm{O}(11.12 \mathrm{~g} / \mathrm{L})$.

For CTVMy/MMy medium, $0.5 \mathrm{~g} / \mathrm{L}$ yeast extract (Roth) was added to the medium and CTVMy+/MMy + contains $5 \mathrm{~g} / \mathrm{L}$ yeast extract (Roth).

Glycerol stocks of cultures were made by adding $500 \mu \mathrm{l}$ sterilized $60 \%$ glycerol to $1.5 \mathrm{~mL}$ culture, in a $2 \mathrm{~mL}$ cryogenic vial (Corning). Stocks were stored at $-80^{\circ} \mathrm{C}$.

In all plate and tube cultures, carbon substrates were used in a concentration of $10 \mathrm{~g} / \mathrm{L}$ unless stated otherwise. For plate cultures, $5 \mathrm{~g} / \mathrm{L}$ gelrite (Roth) was added.

Geobacillus thermodenitrificans T12 was isolated from compost [12]. E. coli $\mathrm{DH} 5 \alpha$ and E. coli TG-90 were used for DNA manipulation and E. coli BL21(DE3) and G. thermodenitrificans T12 were used for protein production. E. coli $\mathrm{DH} 5 \alpha$ and BL21(DE3) were grown at $37{ }^{\circ} \mathrm{C}$ in Luria-Bertani (LB) medium and E. coli TG-90 was grown in LB medium at $30{ }^{\circ} \mathrm{C}$. Wild-type G. thermodenitrificans $\mathrm{T} 12$ was grown at $65{ }^{\circ} \mathrm{C}$ and at $55^{\circ} \mathrm{C}$ when harbouring plasmid DNA to maintain plasmid replication.

\section{DNA isolation, sequencing and assembly}

All strains were grown in LB2 media at $65{ }^{\circ} \mathrm{C}$ in a rotary shaker at 150 RPM. Genomic DNA was isolated from $10 \mathrm{~mL}$ of logarithmic growing cultures of an $\mathrm{OD}_{600}$ of approximately 1.00 AUs by using the MasterPure ${ }^{\text {tax }}$ Gram Positive DNA Purification Kit (Epicentre, Madison, Wisconsin, USA) according to manufacturer's protocol. Genomic DNA was then pooled and sent for sequencing by the company Baseclear B.V. (Leiden, The Netherlands). Paired-end sequence reads were generated using the Illumina HiSeq2500 system. FASTQ sequence files were generated using the Illumina Casava pipeline version 1.8.3. The initial quality assessment was based on data passing the Illumina Chastity filtering. Subsequently, reads containing adapters and/or PhiX control signal were removed using an in-house filtering protocol. Reads were aligned to the genome of G. thermodenitrificans T12, a strain known to contain no functional cellulases, with Bowtie2 v2.2.4 (parameters: -local-no-mixed -no-discordant) [24]. The unaligned reads were assembled with Ray v2.3.1 with a kmer set to 81 . The same unaligned reads were aligned to the assembled scaffolds with Bowtie2 v2.2.4 and converted to sorted BAM files with Samtools v1.1 [25]. The sorted BAM files were used as an input for Pilon v.1.10 [26] for automatic error correction resulting in 2616 scaffolds with a total of $28,814,104$ bp and a n50 of 41,189 bp with average coverage of 715 .
Selection and sequence analysis of metagenome putative cellulases

Prodigal v2.6.1 [27] was used for gene prediction with the G. thermodenitrificans T12 genome as a training set. The predicted proteins were used as input for hmmsearch v3.1b1 [28] to identify possible cellulases with Hidden Markov models (HMMs) from PFAM [29] and dbCAN [30] of all known glycosyl hydrolase (GH) families that contain endoglucanases and/or exoglucanases: GH 1, 5, 6, $7,8,9,10,11,12,26,44,45,48,51,74$ and 124 (accession numbers resp. PF00150.16, PF01341.15, PF00840.18, PF01270.15, PF00759.17, PF00331.18, PF00457.15, PF016 70.14, PF02156.13, PF12891.5, PF02015.14, PF02011.13). Models for GH 51, 74 and 124 were obtained from $\mathrm{dbCAN}$. Proteins fitting the models were functionally annotated with BlastP v2.6.0+ using the TrEMBL v2017_1 protein database. A schematic overview of the procedure is given in Fig. 1.

Initial protein function was based on best hits in the TrEMBL v2017_1 protein database, and then manually filtered on their predicted function. The remaining selection (Table 1) was subject to further sequence analysis, which involved protein model prediction by Phyre2 [31], determination of conserved active site residues and signal peptide prediction by SignalP4.1 [32].

\section{Expression of recombinant putative endoglucanases GE39 and GE40}

Selected putative endoglucanase genes were amplified by high-fidelity PCR using PhusionHF polymerase. The PCR mixes contained $10 \mu \mathrm{l}$ Phusion HF Buffer, 1 unit of Phusion DNA polymerase (Thermoscientific), $100 \mu \mathrm{M}$ of dNTPs, 20 ng DNA, $0.2 \mu \mathrm{M}$ of both the forward primers BG6897 (GCGCCATGGAAATGCTTAAGGTCACTA) for GE39 and BG6899 (GCGCCCATGGAAGACAATA AAGCGTCGGCATAC) for GE40, and the reverse primers BG6898 (CGCCTCGAGTTATAAACTTATACT GGACTGATTTG) for GE39 and BG6900 (CGCC TCGAGCTACTTTCCGGCCATCTTCAA) for GE40. MilliQ was added to a total volume of $50 \mu \mathrm{l}$. PCR products were checked on 1\% agarose gels and products were purified by using a GeneJet PCR purification kit (Fermentas). The PCR products of GE39 were digested with restriction enzymes $N c o I$ and XhoI and purified PCR products of GE40 were digested with restriction enzymes $N c o$ I and $A v a \mathrm{I}$ and subsequently cloned into the pCDF-1b vector (Fig. 2). The recombinant plasmids were introduced to E. coli DH5 $\alpha$ using heat shock competent cells and then plated on selective media. Plasmids were purified using the GeneJET plasmid miniprep kit according to manufacturer's protocol and were subsequently introduced to E. coli BL21(DE3) for enzyme expression. BL21 strains containing the recombinant endoglucanases were cultured overnight in 


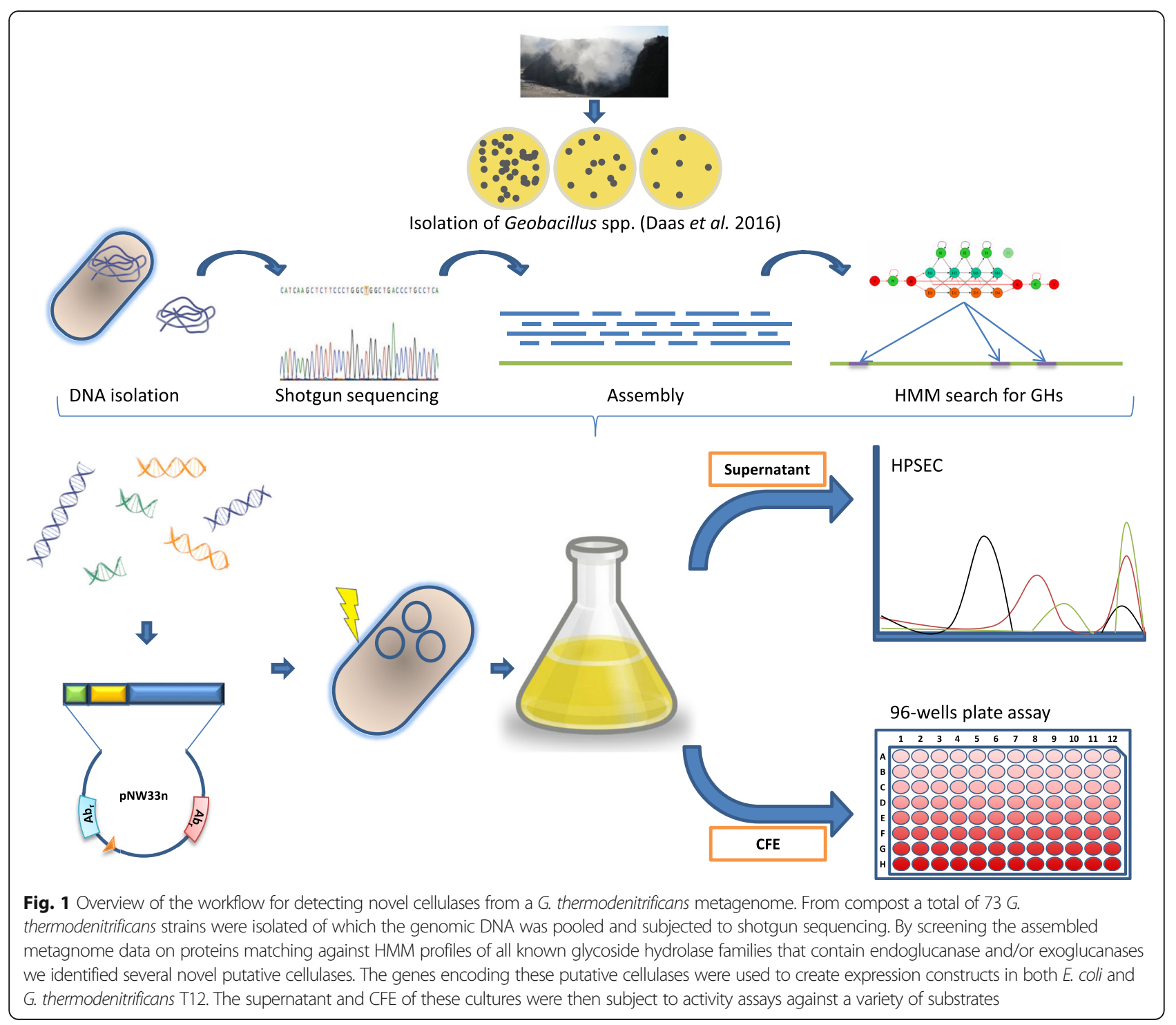

$10 \mathrm{~mL}$ LB medium in a $37{ }^{\circ} \mathrm{C}$ rotary shaker at 150 RPM. Next morning, cultures were cooled on ice for $10 \mathrm{~min}$ prior to being transferred to $50 \mathrm{~mL} \mathrm{LB}$ medium supplemented with $50 \mu \mathrm{g} / \mathrm{ml}$ streptomycin and grown at $20{ }^{\circ} \mathrm{C}$ under constant agitation at 150 RPM. Expression of the endoglucanases was induced using $0.1 \mathrm{mM}$ isopropyl- $\beta$-thioglactopyanoside (IPTG) at an OD600 of approximately 1.00 .

\section{Extraction and characterization of recombinant predicted} endoglucanases GE39 and GE40

The induced E. coli BL21(DE3) cultures $(50 \mathrm{~mL})$ containing the recombinant endoglucanases GE39 and GE40 were collected after $18 \mathrm{~h}$ by centrifugation at $4800 \times g$ for $15 \mathrm{~min}$ at $4{ }^{\circ} \mathrm{C}$. The cells were resuspended in $5 \mathrm{~mL}$ of $200 \mathrm{mM}$ sodium phosphate buffer ( $\mathrm{pH}$ 6.00) and disrupted using a French press at 1200 psi. For

Table 1 Selection of putative endoglucanases retrieved from the metagenome data and their closest orthologs from the TREMBL v080914 protein database

\begin{tabular}{lllllll}
\hline Query & E-value & Bitscore & Hit-Gene ID & AA identity (\%) & Protein names & Organism \\
\hline GE32 & 0 & 2673 & A0A0Q1EJD2 & 100 & GEPA3_1816 & Geobacillus sp. PA-3 \\
GE33 & 0 & 2640 & A0A0Q1EJD2 & 98 & GEPA3_1816 & Geobacillus sp. PA-3 \\
GE39 & 0 & 2559 & A0A0Q1EJD2 & 96 & GEPA3_1816 & Geobacillus sp. PA-3 \\
GE40 & 0 & 1691 & E6TRT3 & 58 & LPXTG-motif cell wall anchor domain protein & Bacillus cellulosilyticus (DSM 2522) \\
\hline
\end{tabular}




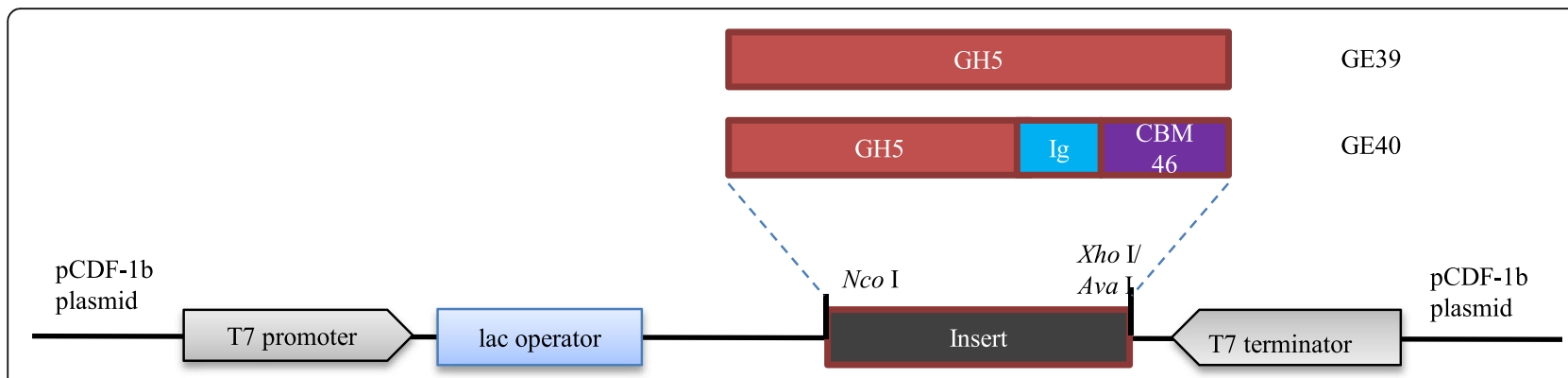

Fig. 2 Expression constructs of two putative endoglucanase encoding genes derived from the G. thermodenitrificans metagenome analysis. Gene GE39 encodes a GH5 catalytic domain and gene GE40 encodes a GH5 catalytic domain followed by an immunoglobulin-like domain (Ig) and a carbohydrate module of family 46 (CBM). Both genes were expressed in E. coli BL21(DE3) using the pCDF-1b plasmid under control of the lac operator

DNA lysis, DNase I was added $(1 \mathrm{mg} / \mathrm{mL})$ to the crude extracts and incubated at room temperature for $15 \mathrm{~min}$. The cell debris was removed by centrifugation at $30,000 \times g$ for $15 \mathrm{~min}$ at $4{ }^{\circ} \mathrm{C}$. The resulting supernatant was filter-sterilized $(0.45 \mu \mathrm{m})$ to remove remaining cell debris and protein concentrations of the obtained cell free extract (CFE) were determined by the Bradford method using the Bradford Reagent Assay Kit (Sigma) with the bovine serum albumin as the standard [33].

To determine saccharolytic activities of the CFE we used a series of chromogenic substrates in a Glycospot Multi CPH 96-wells filter plate [34] (Glycospot, Frederiksberg C, Denmark). Substrates were activated by the addition of $200 \mu \mathrm{L}$ activation solution. Centrifugation $(2700 \times g, 10 \mathrm{~min})$ was applied to remove the solution followed by a double wash with $100 \mu \mathrm{L}$ milliQ. The final reaction mixture in each well consisted of $145 \mu \mathrm{L}$ sodium phosphate buffer ( $\mathrm{pH}$ 6.0) and $5 \mu \mathrm{L}$ of CFE. Plates were then sealed using an aluminium adhesive foil (VWR, Radnor, PA, USA) and incubated at $60{ }^{\circ} \mathrm{C}$ in a rotary shaker at $180 \mathrm{RPM}$. After $24 \mathrm{~h}$ the reaction mixture was collected in the product plate by centrifugation $(2700 \times g, 10 \mathrm{~min})$ and absorbance was measured at $595 \mathrm{~nm}$ (blue) and $517 \mathrm{~nm}$ (red) using a plate reader (Biotek Instruments Inc., Winooski, VT, USA). Negative controls consisted of sodium phosphate buffer and CFE from an E. coli culture containing empty pCDF1b plasmid. The thermostable endoglucanase, CelTM, (Megazyme, Wicklow, Ireland) from Thermotoga maritima was used as positive control at a concentration of $1 \mu \mathrm{g} / \mathrm{mL}$.

To determine exo-activity, we used $3 \mu \mathrm{g}$ of CFE mixed with $200 \mu \mathrm{L}$ of a $200 \mathrm{mM}$ sodium phosphate buffer (pH 6.00). The reaction was started by adding $10 \mu \mathrm{L}$ of $50 \mathrm{mM} p$-nitrophenyl- $\beta$-D-xylopyranoside $(\mathrm{pNP} \beta \mathrm{X}$ ) or $p$-nitrophenyl- $\beta$-D-glucopyranoside (pNP $\beta$ G) (Sigma, St. Louis, MO, USA) and incubated at $60{ }^{\circ} \mathrm{C}$ for $10 \mathrm{~min}$. Negative controls consisted of sodium phosphate buffer and CFE from an E. coli culture containing empty pCDF1b plasmid. Reaction was stopped by adding $1 \mathrm{~mL}$ of $0.5 \mathrm{M}$ bicarbonate and the amount of released pNP was determined by absorbance measurement at $410 \mathrm{~nm}$ and subsequently plotting the data against a standard curve generated using pNP as a substrate. One unit (U) of activity was defined as the release of $1 \mu \mathrm{mol}$ pNP per minute.

\section{Expression constructs of Geobacillus endoglucanases}

Linear constructs of the metagenome derived GE40 encoding gene as well as Geobacillus endoglucanases M1 (GI:523426779), M2 (GI:523426040) and celA (GI:214 003628) were synthetically manufactured by Bio Basic Inc. (Amherst, NY, USA). Constructs were composed of the $\mathrm{P}_{\text {up } \mathrm{T} 12}$ promoter driving expression of the various endoglucanase genes supplemented with the coding sequence for the GtXynA1 (KX962565.1) signal peptide and were separately cloned into the pNW33n vector using restriction enzymes listed in Table 2. Ligation mixes were introduced directly to G. thermodenitrificans T12 as previous attempts in cloning the Geobacillus constructs to E. coli DH5 $\alpha$ and TG90 failed to yield correct transformants. Transformation and recovery of the transformed T12 cells was performed as described before with minor modifications [12].Strain T12 was grown $\mathrm{O} / \mathrm{N}$ in LB2 after which the cells were diluted in $50 \mathrm{~mL}$ fresh LB2 medium $\left(\mathrm{OD}_{600}\right.$ $=0.05)$ in a $250 \mathrm{~mL}$ baffled shake flask. This pre-culture was incubated at $65{ }^{\circ} \mathrm{C}$ in a rotary shaker at $180 \mathrm{RPM}$. When $\mathrm{OD}_{600}$ reached 0.95 , the cells were pelleted by centrifugation $(4800 \times g)$ and washed twice with ice-cold milliQ $(50 \mathrm{~mL})$ and twice with $10 \%$ glycerol $(25 \mathrm{~mL}$ and $10 \mathrm{~mL}$, respectively). Competent cells were then aliquoted $(65 \mu \mathrm{L})$ and incubated with $1 \mu \mathrm{g}$ plasmid DNA for $2 \mathrm{~min}$. Following electroporation ( $2 \mathrm{kV}, 200 \Omega, 25 \mu \mathrm{F})$, cells were recovered for $2 \mathrm{~h}$ in $1 \mathrm{~mL}$ pre-warmed LB2 at $55{ }^{\circ} \mathrm{C}$. Cells were then plated on LB2 agar containing $7 \mu \mathrm{g} / \mathrm{mL}$ chloramphenicol. Colonies were picked after $24 \mathrm{~h}$ of growth at $55{ }^{\circ} \mathrm{C}$ and plasmid presence and integrity was verified by PCR using FW primers BG3665 (5'- GCTCGTTAT AGTCGATCGGTTC-3'), or BG3859 (5' - GTTTGCAAG CAGCAGATTACG-3') for celA, and RV primer BG3664 (5'-AGGGCTCGCCTTTGGGAAG-3'). 
Table 2 Overview of the different elements of all construct and the restriction enzymes used for the insertion of the construct to the pNW33n plasmid

\begin{tabular}{|c|c|c|c|c|c|c|c|}
\hline \multirow[t]{2}{*}{ Gene origin } & \multirow{2}{*}{$\begin{array}{l}\text { Construct } \\
\text { name }\end{array}$} & \multirow[t]{2}{*}{ Promoter } & \multirow{2}{*}{$\begin{array}{l}\text { Signal } \\
\text { peptide }\end{array}$} & \multicolumn{2}{|c|}{ Original protein fragment } & \multirow{2}{*}{$\begin{array}{l}\text { Construct } \\
\text { length } \\
\text { (bp) }\end{array}$} & \multirow{2}{*}{$\begin{array}{l}\text { Restriction } \\
\text { enzymes }\end{array}$} \\
\hline & & & & Start (AA) & End (AA) & & \\
\hline M1 (Gl:523426779) & T12-M1 & $P_{\text {uppT12 }}$ & GtXynA1 & 1 & 389 & 1361 & Acc65l / Pstl \\
\hline M2 (Gl:523426040) & $\mathrm{T} 12-\mathrm{M} 2$ & $P_{\text {uppT12 }}$ & GtXynA1 & 1 & 359 & 1263 & Pstl / HindllI \\
\hline celA (Gl:214003628) & T12-CelA & $P_{\text {uppT12 }}$ & GtXynA1 & 25 & 392 & 1294 & BspHI / EcoRl \\
\hline GE39 & T12-GE39 & $P_{\text {uppT12 }}$ & GtXynA1 & 1 & 488 & 1674 & Acc65l / Pstl \\
\hline GE40wt & T12-GE40wt & $P_{\text {uppT12 }}$ & GE40 & 1 & 538 & 1732 & Acc65I / BamHI \\
\hline GE4O & T12-GE40 & $P_{\text {uppT12 }}$ & GtXynA1 & 28 & 538 & 1732 & Acc65l / BamHI \\
\hline celK (Gl:2978566) & T12-CelK & $P_{\text {uppT12 }}$ & GtXynA1 & 28 & 812 & 2536 & Acc65l /Xbal \\
\hline CelC (Gl:12584559) & T12-CelC & $P_{\text {uppT12 }}$ & GtXynA1 & 1 & 343 & 1219 & BspHI / EcoRl \\
\hline CelS (Gl:145558928) & T12-Cels & $P_{\text {uppT12 }}$ & GtXynA1 & 28 & 674 & 2130 & Pstl / HindllI \\
\hline CelSH (Gl:145558928) & T12-CelSH & $P_{\text {uppT12 }}$ & GtXynA1 & 28 & 674 & 2130 & Pstl / Hindlll \\
\hline
\end{tabular}

Original protein fragment numbers indicate the fragment of protein encoded by the partial gene used to build the different constructs $A A$ amino acid

\section{C. thermocellum cellulases CelC, CelK and CelS}

Linear constructs of the genes encoding C. thermocellum exoglucanase CelK and endoglucanases CelS and CelC were synthetically manufactured by Bio Basic Inc. (Amherst, NY, USA). Constructs were composed of the $\mathrm{P}_{\text {upp T12 }}$ promoter driving expression of the various catalytic domains fused to the carbohydrate binding module of each of the $C$. thermocellum cellulases supplemented with the coding sequence for the GtXynA1 (KX962565.1) signal peptide (Fig. 3). Constructs were separately cloned into the pNW33n vector using restriction enzymes listed in Table 2. Because of the severe mismatch in codon usage between $G$. thermodenitrificans and the gene celS from C. thermocellum, a codon harmonized variant (celSH) was synthesized. The codon landscape and harmonized sequence of celS are given in Additional file 1: Table S1. Constructs were separately cloned into the pNW33n vector and ligation mixes were introduced to $E$. coli TG90. Recovery of the transformed TG90 cells was done at $30{ }^{\circ} \mathrm{C}$ for $2.5 \mathrm{~h}$ in a rotary shaker

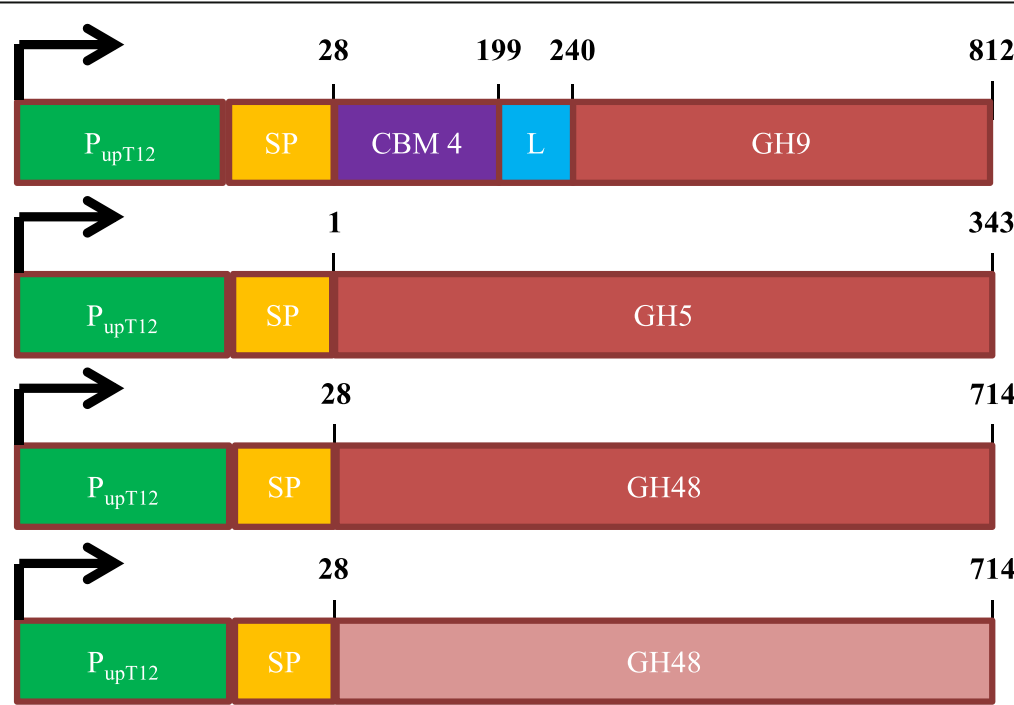

T12-CelK

T12-CelC

T12-CelS

714

T12-CelSH

Fig. 3 Overview C. thermocellum constructs for expression in G. thermodenitrificans T12. Numbers indicate start and end amino acid residues of the original cellulases as deposited in the UniprotKB database. Green: promoter sequence derived from the uracil phosphoribosyltransferase gene native to $G$. thermodenitrificans T12, yellow: signal peptide sequence derived from the endoxylanse encoding gene (GtxynA1) native to G. thermodenitrificans T12, purple: carbohydrate binding domain encoded by celK from C. thermocellum, blue: linker domain of the celK gene from C. thermocellum., red: catalytic domains of the indicated genes, orange: G. thermodenitrificans codon harmonized sequence encoding the catalytic domain of cels 
at 150RPM, as recovery at $37{ }^{\circ} \mathrm{C}$ failed to yield correct transformants. Cells were plated on LB agar containing $12.5 \mu \mathrm{g} / \mathrm{mL}$ chloramphenicol. Colonies were picked after $48 \mathrm{~h}$ of growth at $30^{\circ} \mathrm{C}$ and plasmid presence and integrity was verified by PCR using FW primers BG3665 (or BG3859 for $\mathrm{celC}$ ) and RV primer BG3664. Plasmids containing the correct insert sequence were isolated using JETstar Plasmid Purification MAXI Kit (Genomed, Löhne, Germany) according to manufacturer's protocol. Purified plasmids were subsequently introduced to $G$. thermodenitrificans $\mathrm{T} 12$ as previously described and positive clones were verified by PCR and sequencing of the plasmid insert.

\section{Endoglucanase activity assays}

Cultures (50 mL) of G. thermodenitrificans T12 containing the different cellulase constructs were grown in LB2 medium containing 0.5\% CMC as substrate. After $18 \mathrm{~h}$ of growth at $55{ }^{\circ} \mathrm{C}$ a $10 \mu \mathrm{L}$ sample was taken and spotted on solid LB2 medium containing 0.5\% CMC. Plates were incubated for $24 \mathrm{~h}$ at $55{ }^{\circ} \mathrm{C}$ and subsequently stained for 5 min by flooding the plates with $0.1 \%$ Congo red dye followed by destaining with a $1 \mathrm{M} \mathrm{NaCl}$ solution for $15 \mathrm{~min}$.

The remainder of the T12 cultures were centrifuged $(4800 \times g, 10 \mathrm{~min})$ after which the cell fractions were disrupted using a French press at 1200 psi. The obtained cell lysates were centrifuged $(30,000 \times g, 15 \mathrm{~min})$ to obtain clear CFEs. To determine saccharolytic activities of the CFE we used a series of chromogenic substrates in a Glycospot Multi CPH 96-wells filter plate [34] as described above. Negative controls consisted of sodium phosphate buffer and CFE of a T12 culture containing an empty pNW33n plasmid. The thermostable endoglucanase, CelTM, (Megazyme, Wicklow, Ireland) from Thermotoga maritima was used as positive control at a concentration of $1 \mu \mathrm{g} / \mathrm{mL}$.

Cellulolytic activity of the cultures supernatants was analysed by high performance size exclusion chromatography (HPSEC) on an Ultimate 3000 HPLC system (Thermo Scientific, Sunnyvale, CA, USA) equipped with a set of three TSK-gel columns $(6.0 \mathrm{~mm} \times 15.0 \mathrm{~cm}$ per column) in series (SuperAW4000, SuperAW3000, SuperAW25000, Tosoh Bioscience, Stuttgart, Germany) in combination with a PWX-guard column (Tosoh Bioscience). HPSEC was controlled by the Chromeleon software (Thermo Scientific). Elution took place at $55{ }^{\circ} \mathrm{C}$ with $0.2 \mathrm{M}$ sodium nitrate at a flow rate of $0.6 \mathrm{~mL} / \mathrm{min}$. The eluate was monitored using a refractive index (RI) detector (Shoko Scientific Co., Yokohama, Japan). Calibration was made by using pullulan series (Polymer Laboratories, Union, NY, USA) with a molecular weight in the range of $0.18-788 \mathrm{kDa}$.

\section{Nucleotide sequence accession numbers}

Nucleotide sequences of GE32, GE33, GE39 and GE40 were deposited in GenBank with accession numbers MF969097, MF969098, ATG84609 and ATG84593, respectively. The nucleotide sequence of scaffold_9 from G. thermodenitrificans T81 has been deposited in GenBank with accession number MF170616.

\section{Results}

Selection and sequence analysis of metagenome putative cellulases

In a previous study we showed that several strains of $G$. thermodenitrificans out of a collection of 73 isolates were able to grow on carboxymethyl cellulose, and for some of these strains clear degradation of cellulose was demonstrated by using the Congo red assay [12]. As no cellulases are known for $G$. thermodenitrificans, we performed a metagenome sequencing analysis to retrieve potential cellulases. A total of 82 hits for potential endoglucanases or exoglucanases were identified in the metagenome of 73 G. thermodenitrificans strains using HMM profiles against all glycoside hydrolase families known to contain endoglucanases and/or exoglucanases. After manual inspection of the best hits with the uniprotKB database, we obtained a final selection of four (GE32, GE33, GE39 and GE40) potential endoglucanases which were subject to further analysis. Three of the four putative endoglucanases, GE32, GE33 and GE39, showed high amino acid sequence identity $(>94 \%)$ between each other. Therefore, we assumed these three proteins to have identical activities and we selected GE39 and GE40 for our assays. One scaffold (assigned scaffold 9) contained both the GE39 and GE40 genes and was annotated further using BlastP against the NCBI non-redundant protein database. Comparison of this scaffold with the genome of G. thermodenitrificans T12 revealed that the two genes reside in the hemicellulose utilization (HUS) locus. Great variation in genetic content was observed between the HUS loci of strain T12 and scaffold 9 (Fig. 4). However, the localization of the GE39 gene on scaffold 9 is clustered with $x y l A$ and $x y l B$ which may suggest a role as a $\beta$-xylosidase, in analogy to the XynB3 encoding gene of strain T12. Indeed, the GE39 enzyme shows most amino acid sequence identity (36\%) to the characterized $\beta$-xylosidase (PcXyl5) from Phanerochaete chrysosporium and contains GH5-family conserved glutamine residues at positions E188 and E318 (Fig. 5).

For gene GE4O we could not predict its putative function based on this alignment as we could not relate GE4O to any of the T12 genes nor to any other Geobacillus derived protein from the NCBI non-redundant database. The amino acid sequence of GE40 is closest related (51 and $31 \%$ AA sequence identity) to the well characterized 


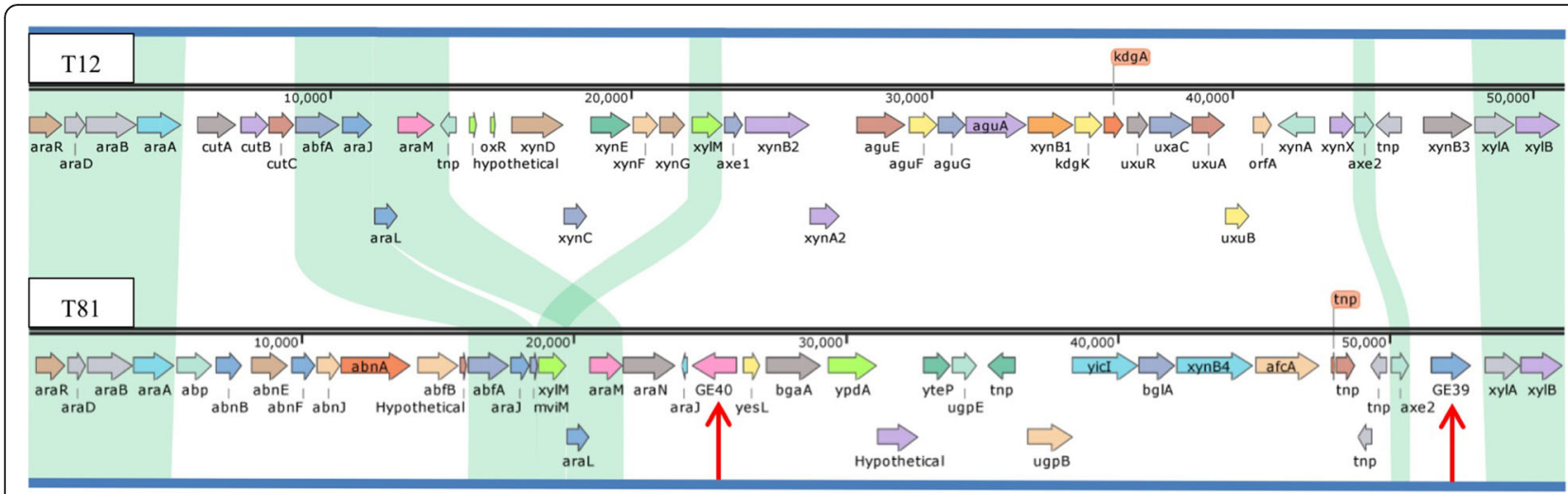

Fig. 4 Overview of the partial HUS loci of G. thermodenitrificans T12 (top) and scaffold 9 (S9, bottom). Annotations were assigned based on protein sequence blast (BlastP) against the National Center for Biotechnology (NCBI) non-redundant protein database. Comparison between the predicted CDSs of the two HUS loci was performed using a localized BlastP analysis in CloneManager v9.51 (Sci-ed software, Denver, CO, USA). Conserved genes are shaded in green, genes coding for endoglucanase GE40 and $\beta$-xylosidase GE39 are indicating by red arrows

GH5 family endoglucanases from Bacillus halodurans (BhCel5b, PDB:4V2X_A) and Bacillus licheniformis (BlCel5b, PDB: 4YZT_A), respectively (Additional file 2: Figure S1). Sequence comparison shows similar protein architecture of both Cel5b proteins and protein GE40. GE40 is comprised of a GH5_4 catalytic domain, an immunoglobulin-like module and a carbohydrate binding module belonging to family 46 (Fig. 6). Deeper analysis of the amino acid sequence of GE40 reveals conserved active site residues of the GH5_4 domain at positions Glu-178 and Glu-296, and a conserved residue active in ligand-binding of the CBM to be Trp-501 (Fig. 6) [35, 36]. The location of Glu-178 and Glu-296 on the C-termini of the fourth and seventh $ß$-strand respectively, is in accordance with the known position of active site residues in enzymes belonging to the GH5 family [35, 37].

Cellulolytic activity of the GE40 and GE39 proteins produced in E. coli was measured using the solubilized fraction of the chromogenic substrates in a Glycospot Multi CPH assay plate (Additional file 3: Table S2). CFE of the GE40 expressing $E$. coli culture showed high activity towards cellulose and barley derived $\beta$-glucan. In contrast, CFE of the GE39 producing E. coli culture showed no activity to any of the chromogenic substrates (Fig. 7, Additional file 3: Table S2). However, it showed activity towards $p$-nitrophenyl- $\beta$-D-xylopyranoside (55 U/

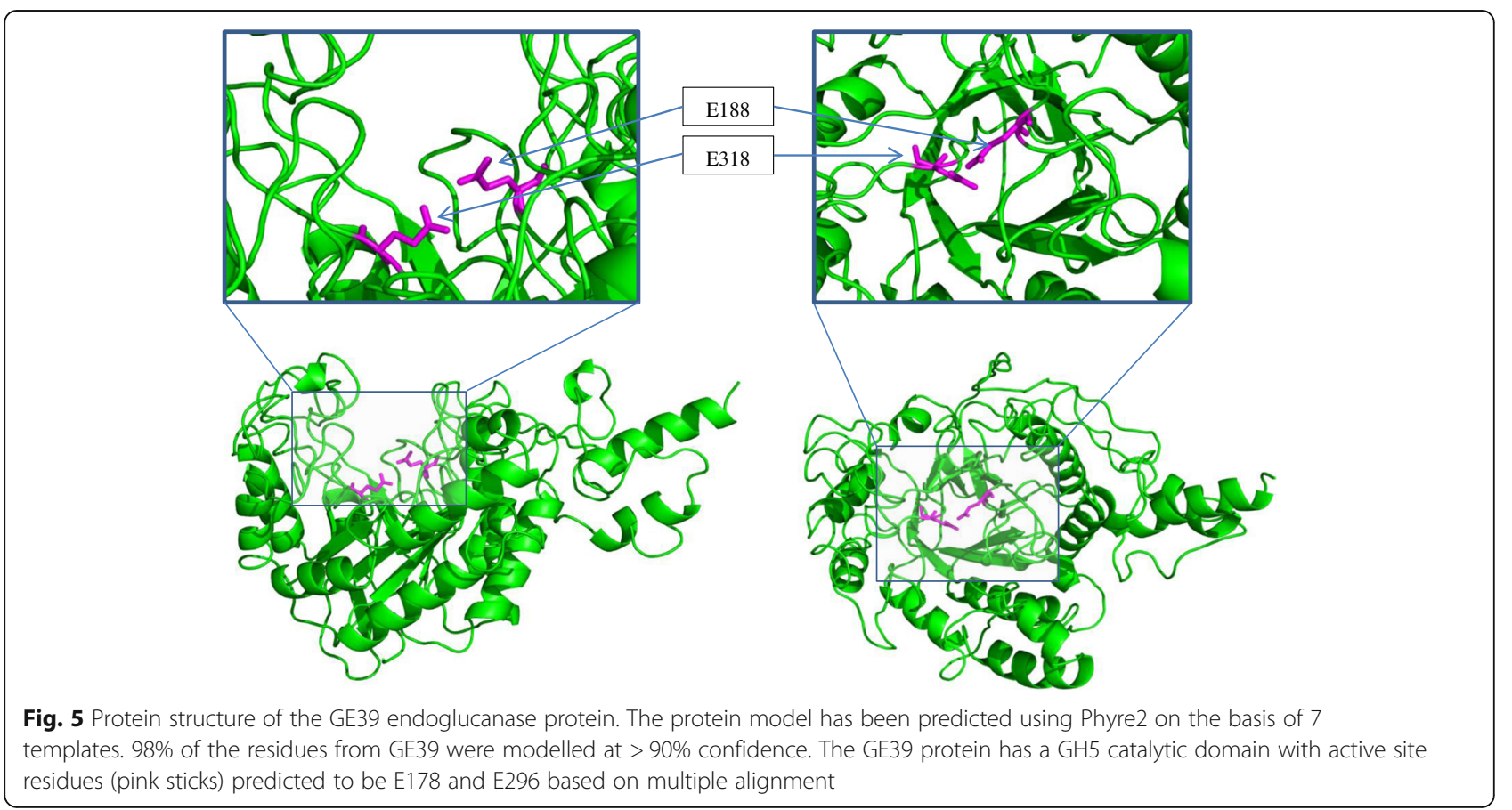




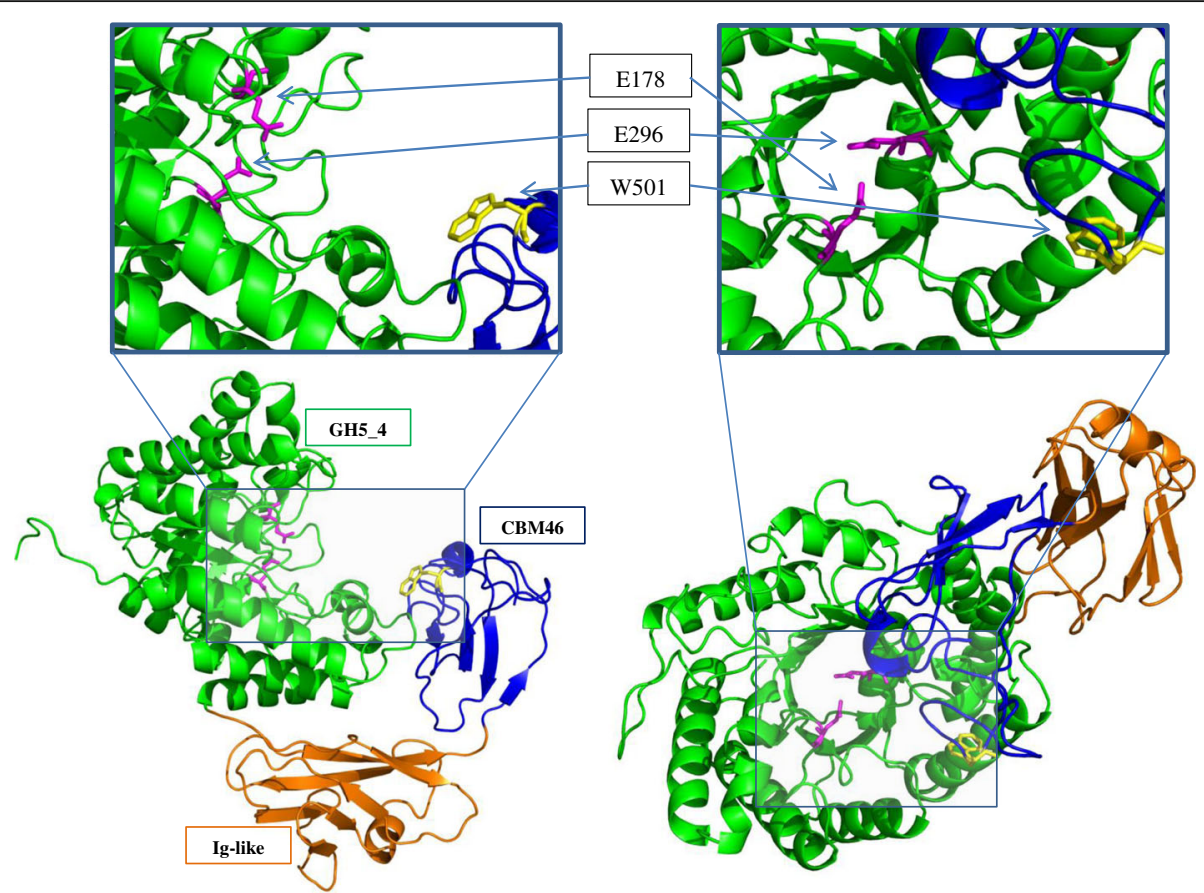

Fig. 6 Protein structure of the GE40 endoglucanase protein. The protein model has been predicted on the basis of the crystal structure of a Bacillus halodurans endoglucanase (BhCel5b; PDB:4V2X_A). 92\% of the residues from GE40 were modelled at > 90\% confidence. The GE40 protein contains an N-terminal GH5_4 catalytic domain, an immunoglobulin-like domain and a C-terminal CBM46. Active site residues were to be E178 and E296 (pink sticks). The tryptophan residue at position W501 (yellow stick) was predicted to be involved in ligand binding

mg) along with some side activity towards $p$-nitrophenyl- $\beta$-d-glucopyranoside $(11 \mathrm{U} / \mathrm{mg})$. We therefore conclude that GE39 is a $\beta$-xylosidase.

\section{G. thermodenitrificans cellulolytic activity assays}

The GE40 metagenome endoglucanase, the Geobacillus endoglucanase encoding genes $M 1, M 2$ and celA, and the $C$. thermocellum cellulase encoding genes (celK, celC and celS) were used to create expression constructs for G. thermodenitrificans T12. The chosen genes from $C$. thermocellum have been reported to be highly expressed in $C$. thermocellum when grown on cellulosic and lignocellulosic substrates and are therefore expected to be of great importance for the cellulolytic activity of $C$. thermocellum [18-20]. From these genes, only the catalytic domains and, if present, the carbohydrate binding modules were used and fused with the GtXynA (extracellular endoxylanase) signal peptide and the $\mathrm{P}_{\text {upp } \mathrm{T} 12}$ promoter sequence (derived from the uracil phosphoribosyltransferase encoding gene of strain T12), which have both successfully been used for heterologous protein production in G. thermodenitrificans T12 [12]. For endoglucanase GE40, we created two constructs; T12-GE40wt: the native gene under control of the $\mathrm{P}_{\text {uрp } \mathrm{T} 12}$

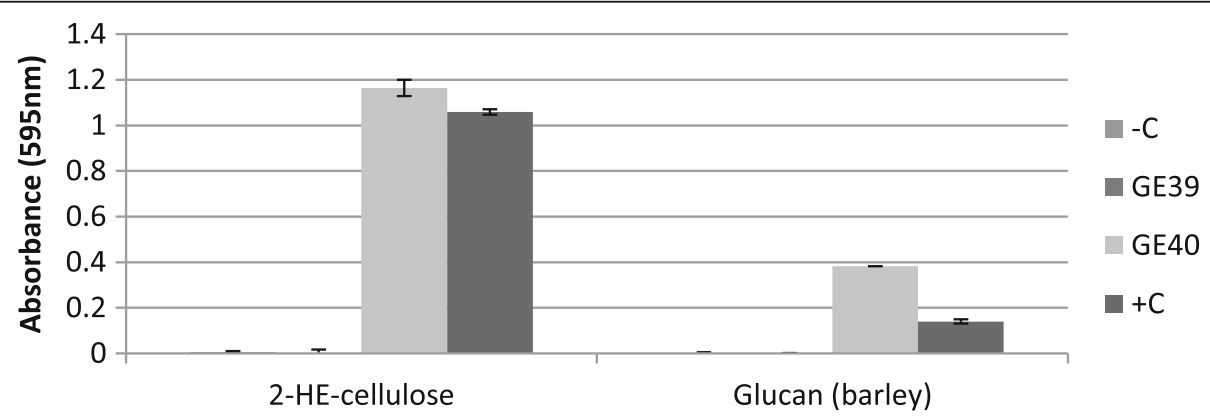

Fig. 7 Enzyme activity of CFE from GE39 and GE40 expressing E. coli BL21(DE3) cultures. CFE was incubated at a pH of 6.0 on a series of chromogenic substrates and incubated for $24 \mathrm{~h}$ at $60^{\circ} \mathrm{C}$ in a rotary shaker (180 RPM). Degradation of the substrate by cellulolytic activity was measured by colorimetric measurements of the solubilized chromogenic oligosaccharides at $595 \mathrm{~nm}$ 
promoter and T12-GE40: as T12-GE40wt but with the GtXynA1 signal peptide as replacement for the original signal peptide. Also, for the expression of $C$. thermocellum exoglucanase celS we created two constructs; one with the original sequence (T12-celS) and one with a codon harmonised sequence $\left(\mathrm{T} 12-\mathrm{cel}^{H}{ }^{H}\right.$ ). Constructs were introduced to strain T12 using the pNW33n vector and functional activities were tested in vivo using the Congo red assay and HPSEC analysis. Strains harbouring constructs with the $C$. thermocellum celC, celS and celS ${ }^{H}$ genes lack cellulase activity. However, strains harbouring a construct derived from $C$. thermocellum celK, the Geobacillus celA or the GE4O gene showed activity against amorphous cellulose (Additional file 4: Figure S2). This activity was also confirmed by HPSEC analysis for constructs T12-CelK and T12-CelA, indicated by the reduced MW of the CMC peak eluting between 8 and $10 \mathrm{~min}$ (Fig. 8). The activity of T12-GE40 was too low to be visualized on HPSEC.

\section{Discussion}

G. thermodenitrificans $\mathrm{T} 12$ has been shown to ferment biomass derived feedstocks with limited need for additional enzymes mainly due to its xylanolytic and pectinolytic activity and genetic accessibility [12]. The requirement for a true CBP organism to hydrolyze both hemicellulose and cellulose has not been achieved yet for G. thermodenitrificans and, despite major efforts to find cellulolytic Geobacillus spp. [8, 11-13, 23, 38], to date there is no evidence of a strain capable of efficient cellulose conversion. The endoglucanase CelA from Geobacillus sp. 70PC53 is currently the only characterized cellulolytic enzyme native to Geobacillus spp. [11, 13]. Two more Geobacillus derived enzymes have been proposed to be endoglucanases, M1 and M2 from Geobacillus sp. WSUCF1. The study describing the characterization of endoglucanases M1 and M2 shows activity of the M1 and M2 proteins against cellulose [11]. However, in this study we could not detect degradation of $\mathrm{CMC}$, not even under constitutive expression of the $M 1$ and $M 2$ genes. Sequence analysis against the UniprotKB database gives highest sequence identities against peptidases and additionally, we could not identify active site residues based on sequence comparison to other endoglucanases of the GH5 family. Therefore, we assume that these enzymes are most likely peptidases and not true endoglucanases.

We screened the metagenome of 73 G. thermodenitrificans strains for genes that match with the HMM profiles of every glycoside hydrolase family known to contain cellulases yielding a total of 82 proteins that matched with one or more profiles. To reduce the number of false positives obtained in this approach, a more reliable cut-off threshold can be made using validated proteins of each protein family as a training set against other families. Two putative endoglucanases (GE39 and GE40) of glycoside hydrolase family 5 were identified that have been shown to be located in the HUS locus of the isolation strain. The genetic variation between the

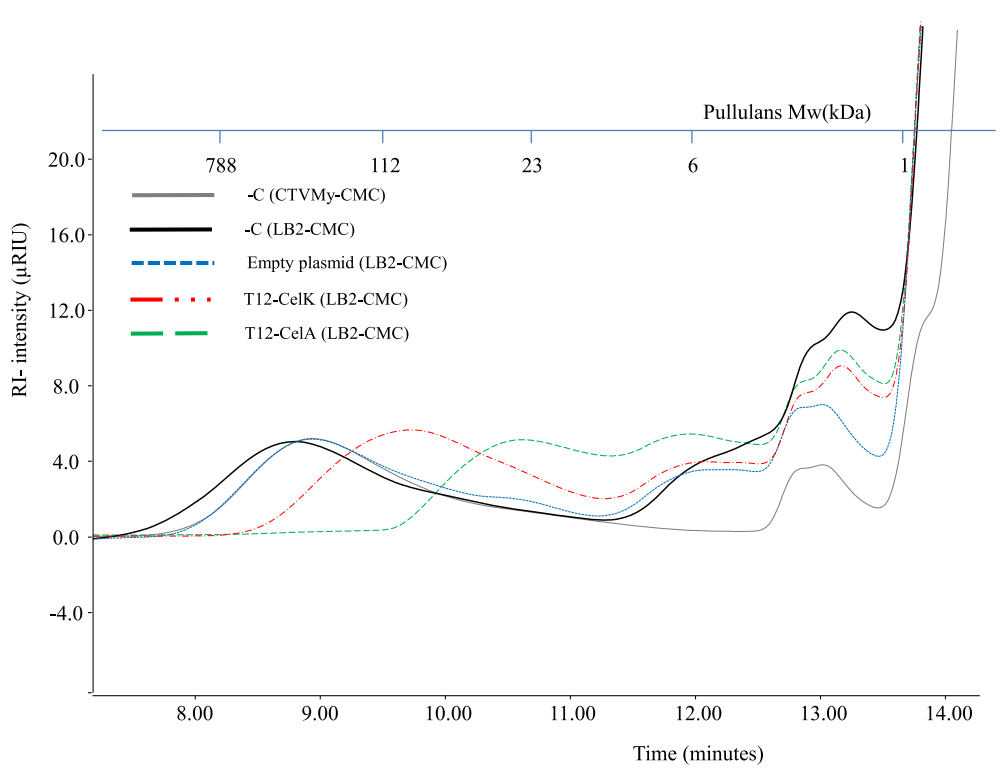

Fig. 8 HPSEC analysis of carboxymethylcellulose (CMC) degradation by G. thermodenitrificans T12. Cultures were grown for $24 \mathrm{~h}$ on LB2 with $1 \%$ CMC. The degradation of the cellulose is visualized by the change in molecular weight of the peak eluting between 8 and 9 min. Both cultures expressing CelA (T12-CelA, green) and CelK (T12-CelK, red) show a clear degradation of cellulose in contrast to the empty plasmid control (Empty plasmid, blue). Negative controls (-C) consisting of non-inoculated media show some effect of yeast extract around an elution time of 12-14 min 
HUS locus of T12 and the partial HUS locus encoded by scaffold 9 is remarkable, as previous HUS loci comparison between three G. thermodenitrificans strains showed no variation in genetic content [16]. The protein architecture of GE39 contains a GH5 catalytic domain, and active site residues have been identified at positions E188 and E318. The GE39 sequence shows identity to several endoglucanases (Additional file 2: Figure S1) and structure modeling of GE39 revealed a folding similar to a GH5 exo-1,3- $\beta$-glucanase from $S$. cerevisiae. Based on structure modeling we expected GE39 to belong to the GH family 5 glucanases. However, protein alignment reveals highest identity $(36 \%)$ to a GH5 $\beta$-xylosidase from Phanerochaete chrysosporium (rPcXyl5) [39]. For rPcXyl5 it was shown that it was most active against $p$-nitrophenyl- $\beta$-D-xylopyranoside $(\mathrm{pNPbX})$ with minor activities against xylan, which is in agreement with the lack of activity seen in our activity assays on chromogenic xylan and cellulose substrates. Likewise, we found GE39 to be active against $p$-nitrophenyl- $\beta$-D-xylopyranoside. In contrast to $\mathrm{rPcXy15}$, the GE39 $\beta$-xylosidase showed side activity against $p$-nitrophenyl- $\beta$-D-glucopyranoside (pNP $\beta X)$.

Where enzyme GE39 did not show glucanase activity, enzyme GE40 was demonstrated to be active against 2-HE-cellulose, CM-cellulose and barley glucan. The protein architecture of GE40 is comprised of a GH5_4 catalytic domain, an immunoglobulin-like module and a carbohydrate binding module of family 46 (Fig. 6). Family 46 CBMs, with the ability to bind cellulose and glucan, are always located on the C-terminus of enzymes containing a GH5_4 catalytic domain and an immunoglobulin (Ig)-like module. The Ig-like module is believed to act as a structural hinge, thereby holding the catalytic domain and the CBM in position for optimal enzymatic activity [36]. The CBM acts in synergy with the GH5_4 catalytic domain to bind glucans and thereby aid in the hydrolytic cleavage of the substrate [35]. Although cellulase activity was clearly demonstrated in the CFE of a GE4O expressing $E$. coli culture, we could only detect minor activity when GE40 was expressed in G. thermodenitrificans T12 (Additional file 4: Figure S2). Furthermore, SDS PAGE analysis of the cell lysate from a GE40 expressing T12 culture did not show heterologous protein formation and no additional protein bands were visualized (data not shown). We have provided evidence that GE40 is a novel endoglucanase, however, further development of suitable promoters and/or signal peptide sequences is needed to increase protein yield and thereby the extracellular activity required for efficient cellulose conversion.
In an attempt to complement the cellulolytic machinery of G. thermodenitrificans, we introduced several cellulases from C. thermocellum into strain T12. By removing the dockerin domain we created smaller constructs that were expected to be easier to introduce to G. thermodenitrificans T12. The removal of the dockerin domain of CelK and CelS was shown not to reduce the enzymatic activity [40] and activity of both endoglucanases and exoglucanases from $C$. thermocellum against amorphous cellulose has been demonstrated [41]. Therefore, we hypothesize that their removal has not been instrumental in the lack of activity seen in our study. The lack of activity observed for CelS, CelSH and CelC, is possibly caused by insufficient protein production as we did not detect heterologous protein by SDS-PAGE analysis on the intracellular protein fraction (data not shown) and no intracellular or extracellular enzyme activity was detected by using chromogenic substrates and HPSEC (data not shown). We therefore hypothesize that problems at the transcription or early translational stage hamper production of functional enzymes. The fused signal peptides may also impact the efficiency, but as no clear intracellular accumulation was observed, we consider this not a major restriction at this stage. Cultures producing T12-CelK, T12-CelA and T12-GE40 did show both extracellular (Fig. 8, Additional file 4: Figure S2) and intracellular cellullolytic activity (data not shown). When G. thermodenitrificans strains that were demonstrated to be able to degrade cellulose were grown in liquid cultures containing $\mathrm{CMC}$ as sole carbon source, we were unable to detect organic acids. This observation once more indicates a lack of sufficient activity due to low expression of the enzymes and a need for further optimization.

\section{Conclusions}

This study shows the potential of metagenome mining for the discovery of novel cellulases. Metagenome-derived enzyme GE39 was shown to be a novel GH5 $\beta$-xylosidase with some $\beta$-glucosidase activity. Enzyme GE40 was shown to be a novel GH5 endoglucanase that is active against amorphous cellulose and barley glucan and had $55 \%$ identity to its closest ortholog BhCel5b from Bacillus halodurans. Enzyme GE40 is the second endoglucanase retrieved from Geobacillus and the first found in G. thermodenitrificans.

We also demonstrated the ability of Geobacillus thermodenitrificans T12 to act as a host for heterologous cellulase expression. Although the degradation of cellulose by strain T12 still requires optimization, as activities remained low, the methods described in this study provide a starting point for further development of Geobacillus spp. as potential hosts for consolidated bioprocessing. 


\section{Additional files}

Additional file 1: Table S1. Codon harmonization of cels from C. thermocellum. An overview of the codon harmonization method used to adapt the $C$. thermocellum derived exoglucanase encoding gene cels for expression in $\mathrm{G}$. thermodenitrificans. (XLSX $78 \mathrm{~kb}$ )

Additional file 2: Figure S1. Phylogenetic tree of GH5 family hydrolases. The evolutionary history was inferred by using the Maximum Likelihood method based on the JTT matrix-based model [42]. The percentage of trees in which the associated taxa clustered together is shown next to the branches. Initial tree(s) for the heuristic search were obtained automatically by applying Neighbor-Join and BioNJ algorithms to a matrix of pairwise distances estimated using the Jones Thornton Taylor (JTT) model, and then selecting the topology with superior log likelihood value. The tree is drawn to scale, with branch lengths measured in the number of substitutions per site. The analysis involved 27 amino acid sequences. All positions containing gaps and missing data were eliminated. There were a total of 198 positions in the final dataset. Evolutionary analyses were conducted in MEGA7 [43]. Open circle: eukaryotic origin; closed triangle: thermophilic organism; closed diamond: sequences obtained in this study. (PDF $12 \mathrm{~kb}$ )

Additional file 3: Table S2. Overview of measured absorbance of different chromogenic substrates after incubation with the metagenome derived putative cellulases GE39 and GE40 expressed from E. coli. Overview of measured absorbance of different chromogenic substrates after incubation with the metagenome derived putative cellulases GE39 and GE40 expressed from E. coli. The final reaction mixture in each well of the substrate plate consisted of $145 \mu \mathrm{L}$ sodium phosphate buffer ( $\mathrm{pH}$ 6.0) and $5 \mu \mathrm{L}$ of CFE. Plates were then sealed using an aluminum adhesive foil and incubated at $60{ }^{\circ} \mathrm{C}$ in a rotary shaker at $180 \mathrm{RPM}$. After $24 \mathrm{~h}$ the reaction mixture was collected in a product plate by centrifugation (2700 $\times \mathrm{g}, 10 \mathrm{~min}$ ) and absorbance was measured at $595 \mathrm{~nm}$ (blue) and $517 \mathrm{~nm}$ (red) using a plate reader (Biotek Instruments Inc., Winooski, VT, USA). Negative control consisted of sodium phosphate buffer and CFE from an E. coli culture containing empty pCDF1b plasmid. The thermostable endoglucanase, CelTM, (Megazyme, Wicklow, Ireland) from Thermotoga maritima was used as positive control $(+C)$ at a concentration of $1 \mu \mathrm{g} / \mathrm{mL}$. Values for the negative control have been subtracted. CFE of the GE40 expressing E. coli culture showed high activity towards cellulose and barley derived $\beta$-glucan. In contrast, CFE of the GE39 producing E. coli culture showed no activity to any of the chromogenic substrates. (PDF $147 \mathrm{~kb}$ )

Additional file 4: Figure S2. Congo red assays of cellulase expressing G. thermodenitrificans cultures. Congo red assays of $G$. thermodenitrificans cultures grown on LB2 medium with 1\% carboxymethylcellulose. Each culture produces a different cellulase. $\varnothing$ : empty plasmid (pNW33n) control; CelA: GH5 endoglucanase CelA (Geobacillus 70PC53); CelK: GH9 exoglucanase (C. thermocellum); GE40wt: GH5 endoglucanase (Geobacillus metagenome derived) containing its native signal peptide; GE40: GH5 endoglucanase (Geobacillus metagenome derived). (PDF 48 kb)

\section{Funding}

This work was financially supported by BE-Basic (https://www.be-basic.org/) and Corbion as part of the BE-Basic C3-acids project.

\section{Availability of data and materials}

The datasets used and/or analyzed during the current study are available from the corresponding author on reasonable request.

\section{Authors' contributions}

MD designed the study, performed part of the cloning work, data analysis and enzymatic assays. He also drafted the manuscript. BN performed the metagenome screen, analyzed the data and assisted in drafting the manuscript. AvdW assisted the design of the study, cloning, enzyme assays and in drafting the manuscript. BG and FJ assisted in the design of the study, performed the cloning and enzyme assays and assisted in drafting the manuscript. JvdO and RvK coordinated the study and revised the manuscript. All authors read and approved on the final manuscript.

\section{Ethics approval and consent to participate}

This article does not contain any studies with human participants or animals performed by any of the authors.

\section{Consent for publication}

Not applicable.

\section{Competing interests}

The authors declare to have no conflict of interest. RvK is employed by the biotech company Corbion (Gorinchem, The Netherlands).

\section{Publisher's Note}

Springer Nature remains neutral with regard to jurisdictional claims in published maps and institutional affiliations.

\section{Author details}

${ }^{1}$ Laboratory of Microbiology, Wageningen University, Stippeneng 4, 6708 , WE, Wageningen, The Netherlands. 'Laboratory of Systems and Synthetic Biology, Wageningen University, Stippeneng 4, 6708, WE, Wageningen, The Netherlands. ${ }^{3}$ Corbion, Arkelsedijk 46, 4206, AC, Gorinchem, The Netherlands.

Received: 9 October 2017 Accepted: 14 June 2018

Published online: 27 June 2018

\section{References}

1. Lynd LR, Weimer PJ, van Zyl ISP WH. Microbial cellulose utilization: fundamentals and biotechnology. Microbiol Mol Biol Rev. 2002;66:506-77.

2. Akinosho H, Yee $\mathrm{K}$, Close D, Ragauskas A. The emergence of Clostridium thermocellum as a high utility candidate for consolidated bioprocessing applications. Front Chem. 2014;2:66.

3. Turner P, Mamo G, Karlsson EN. Potential and utilization of thermophiles and thermostable enzymes in biorefining. Microb Cell Fact. 2007;6:9.

4. Argyros DA, Tripathi SA, Barrett TF, Rogers SR, Feinberg LF, Olson DG, et al. High ethanol titers from cellulose by using metabolically engineered thermophilic, anaerobic microbes. Appl Environ Microbiol. 2011;77:8288-94.

5. Blumer-Schuette SE, Kataeva I, Westpheling J, Adams MW, Kelly RMCN. Extremely thermophilic microorganisms for biomass conversion: status and prospects. Curr Opin Biotechnol. 2008;19:210-7.

6. Zhang YP, Lynd LR. Cellulose utilization by Clostridium thermocellum: bioenergetics and hydrolysis product assimilation. Proc Natl Acad Sci U S A. 2005;102:7321-5.

7. Cripps RE, Eley K, Leak DJ, Rudd B, Taylor M, Todd M, et al. Metabolic engineering of Geobacillus thermoglucosidasius for high yield ethanol production. Metab Eng. 2009;11:398-408.

8. Hussein $\mathrm{AH}$, Lisowska BK, Leak DJ. The genus Geobacillus and their biotechnological potential. Adv Appl Microbiol. 2015;92:1-48.

9. Shulami S, Shenker O, Langut Y, Lavid N, Gat O, Zaide G, et al. Multiple regulatory mechanisms control the expression of the Geobacillus stearothermophilus gene for extracellular xylanase. J Biol Chem. 2014;289: 25957-75

10. Daas MJA, Vriesendorp B, van de Weijer AHP, van der Oost J, van Kranenburg R. Complete genome sequence of Geobacillus thermodenitrificans T12, a potential host for biotechnological applications. Curr Microbiol. 2018;75:49-56.

11. Rastogi G, Bhalla A, Adhikari A, Bischoff KM, Hughes SR, Christopher LP, et al Characterization of thermostable cellulases produced by Bacillus and Geobacillus strains. Bioresour Technol. 2010;101:8798-806.

12. Daas MJA, van de Weijer AHP, de Vos WM, van der Oost J, van Kranenburg R. Isolation of a genetically accessible thermophilic xylan degrading bacterium from compost. Biotechnol Biofuels. 2016;9:210.

13. $\mathrm{Ng} I S$, Li CW, Yeh YF, Chen PT, Chir JL, Ma CH, et al. A novel endoglucanase from the thermophilic bacterium Geobacillus sp. 70PC53 with high activity and stability over a broad range of temperatures. Extremophiles. 2009;13:425-35.

14. Bartosiak-Jentys J, Hussein AH, Lewis CJ, Leak DJ. Modular system for assessment of glycosyl hydrolase secretion in Geobacillus thermoglucosidasius. Microbiol (United Kingdom). 2013;159:1267-75.

15. Suzuki $H$, ichi $Y K$, Ohshima T. Polysaccharide-degrading thermophiles generated by heterologous gene expression in Geobacillus kaustophilus HTA426. Appl Environ Microbiol. 2013;79:5151-8. 
16. De Maayer P, Brumm PJ, D a M, D a C. Comparative analysis of the Geobacillus hemicellulose utilization locus reveals a highly variable target for improved hemicellulolysis. BMC Genomics. 2014;15:836.

17. Lan Thanh Bien T, Tsuji S, Tanaka K, Takenaka S, Yoshida K. Secretion of heterologous thermostable cellulases in Bacillus subtilis. J Gen Appl Microbiol. 2014;60:175-82.

18. Gold ND, Martin VJJ. Global view of the Clostridium thermocellum cellulosome revealed by quantitative proteomic analysis. J Bacteriol. 2007; 189:6787-95.

19. Rydzak T, McQueen PD, Krokhin OV, Spicer V, Ezzati P, Dwivedi RC, et al. Proteomic analysis of Clostridium thermocellum core metabolism: relative protein expression profiles and growth phase-dependent changes in protein expression. BMC Microbiol. 2012;12:214.

20. Wei H, Fu Y, Magnusson L, Baker JO, Maness PC, Xu Q, et al. Comparison of transcriptional profiles of Clostridium thermocellum grown on cellobiose and pretreated yellow poplar using RNA-seq. Front Microbiol. 2014;5:142.

21. Fong JCN, Svenson CJ, Nakasugi K, Leong CTC, Bowman JP, Chen B, et al. Isolation and characterization of two novel ethanol-tolerant facultativeanaerobic thermophilic bacteria strains from waste compost. Extremophiles. 2006;10:363-72.

22. Sizova MV, Izquierdo JA, Panikov NS, Lynd LR. Cellulose-and xylan-degrading thermophilic anaerobic bacteria from biocompost. Appl Environ Microbiol. 2011;77:2282-91.

23. Bosma EF, van de Weijer AHP, Daas MJA, van der Oost J, de Vos WM, van Kranenburg R. Isolation and screening of thermophilic bacilli from compost for electrotransformation and fermentation: characterization of Bacillus smithii ET 138 as a new biocatalyst. Appl Environ Microbiol. 2015;81:1874-83.

24. Langmead B, Salzberg SL. Fast gapped-read alignment with bowtie 2. Nat Methods. 2012;9:357-9.

25. Li H, Handsaker B, Wysoker A, Fennell T, Ruan J, Homer N, et al. The sequence alignment/map format and SAMtools. Bioinformatics. 2009;25: 2078-9.

26. Walker BJ, Abeel T, Shea T, Priest M, Abouelliel A, Sakthikumar S, et al. Pilon: an integrated tool for comprehensive microbial variant detection and genome assembly improvement. PLoS One. 2014;9:e112963.

27. Hyatt D, Chen G-L, Locascio PF, Land ML, Larimer FW, Hauser LJ. Prodigal: prokaryotic gene recognition and translation initiation site identification. BMC Bioinformatics. 2010;11:119.

28. Eddy SR. Accelerated profile HMM searches. PLoS Comput Biol. 2011;7: e1002195.

29. Finn RD, Coggill P, Eberhardt RY, Eddy SR, Mistry J, Mitchell AL, et al. The Pfam protein families database: towards a more sustainable future. Nucleic Acids Res. 2016;44:D279-85.

30. Yin Y, Mao X, Yang J, Chen X, Mao F, Xu Y. DbCAN: a web resource for automated carbohydrate-active enzyme annotation. Nucleic Acids Res. 2012 40:W445-51.

31. Kelley LA, Mezulis S, Yates CM, Wass MN, Sternberg MJE. The Phyre2 web portal for protein modeling, prediction and analysis. Nat Protoc. 2015;10: 845-58

32. Petersen TN, Brunak S, von Heijne G, Nielsen H. SignalP 4.0: discriminating signal peptides from transmembrane regions. Nat Methods. 2011;8:785-6.

33. Bradford MM. A rapid and sensitive method for the quantitation of microgram quantities of protein utilizing the principle of protein-dye binding. Anal Biochem. 1976;72:248-54.

34. Kračun SK, Schückel J, Westereng B, Thygesen LG, Monrad RN, Eijsink VGH, et al. A new generation of versatile chromogenic substrates for highthroughput analysis of biomass-degrading enzymes. Biotechnol Biofuels. 2015:8:70.

35. Venditto I, Najmudin S, Luís AS, Ferreira LMA, Sakka K, Knox JP, et al. Family 46 carbohydrate-binding modules contribute to the enzymatic hydrolysis of xyloglucan and beta-1,3-1,4-glucans through distinct mechanisms. J Biol Chem. 2015;290:10572-86.

36. Liberato MV, Silveira RL, Prates ÉT, de Araujo EA, Pellegrini VOA, Camilo CM, et al. Molecular characterization of a family 5 glycoside hydrolase suggests an induced-fit enzymatic mechanism. Sci Rep. 2016;6:23473.

37. Henrissat B, Callebaut I, Fabrega S, Lehn P, Mornon JP, Davies G. Conserved catalytic machinery and the prediction of a common fold for several families of glycosyl hydrolases. Proc Natl Acad Sci U S A. 1995;92:7090-4.

38. Tai SK, Lin HPP, Kuo J, Liu JK. Isolation and characterization of a cellulolytic Geobacillus thermoleovorans T4 strain from sugar refinery wastewater. Extremophiles. 2004;8:345-9.
39. Huy ND, Le NC, Seo JW, Kim DH, Park SM. Putative endoglucanase PCGH5 from Phanerochaete chrysosporium is a beta-xylosidase that cleaves xylans in synergistic action with endo-xylanase. J Biosci Bioeng. 2015;119:416-20.

40. Vazana Y, Moraïs S, Barak Y, Lamed R, Bayer EA. Interplay between Clostridium thermocellum family 48 and family 9 cellulases in cellulosomal versus noncellulosomal states. Appl Environ Microbiol. 2010;76:3236-43.

41. Berger E, Zhang D, Zverlov W, Schwarz WH. Two noncellulosomal cellulases of Clostridium thermocellum, Cel91 and Cel48Y, hydrolyse crystalline cellulose synergistically. FEMS Microbiol Lett. 2007;268:194-201.

42. Jones DT, Taylor WR, Thornton JM. The rapid generation of mutation data matrices from protein sequences. Comput Appl Biosci. 1992:8:275-82.

43. Kumar S, Stecher G, Tamura K. MEGA7: molecular evolutionary genetics analysis version 7.0 for bigger datasets. Mol Biol Evol. 2016:33:1870-4.

\section{Ready to submit your research? Choose BMC and benefit from:}

- fast, convenient online submission

- thorough peer review by experienced researchers in your field

- rapid publication on acceptance

- support for research data, including large and complex data types

- gold Open Access which fosters wider collaboration and increased citations

- maximum visibility for your research: over $100 \mathrm{M}$ website views per year

At BMC, research is always in progress.

Learn more biomedcentral.com/submissions 